2,500. A number of other community centres, often built by voluntary labour, have been established in other areas. The Castle of Anamabu has been used to accommodate parties of schoolboys from Ashanti, who spent a fortnight by the sea while taking part in courses on citizenship.

\title{
Visual Aids in Education
}

A SERIES of film strips covering a number of geographical regions has been prepared for the London County Council. Each film is accompanied by descriptive notes for the use of teachers, and is designed to illustrate the physical features of the region, the occupations, characteristics, and living-conditions of the people, aspects of urban life, transport, communications, \&c. The film strips and other visual aids are produced by Educational Products Ltd., Bradford Road, East Ardsley, Wakefield, Yorks.

\section{Sudan Publications Bureau}

IN 1950, as part of the programme for producing reading-matter for, and encouraging authorship among, literate Southern Sudanese, a quarterly magazine, Future, was started. It is edited, illustrated, and printed in Juba on a small rotary offset lithographic machine. No. 3, September I95 I, contains an excellent illustrated article for teachers on the preparation of lessons, use of blackboard and other equipment, presentation of material, apportioning of time, \&c.; short articles on subjects of general and topical interest, notes on world affairs, on schools, sport, scouting, \&c., stories, puzzles, and a section written in Arabic (see also Africa, vol. xxi, 4, p. 333).

\section{MARGARET WRONG PRIZE}

This Prize will be offered annually by the Trustees of the Margaret Wrong Memorial Fund for original literary work by writers of African race living in a part of Africa to be decided upon each year by the Trustees.

\section{Regulations for 1952}

1. A silver medal and a money prize not exceeding $£ 5$ will be offered in 1952.

2. In 1952 manuscripts are invited from Northern and Southern Rhodesia, Nyasaland, Portuguese East Africa and Angola.

3. The length of manuscripts should be not less than 5,000 or more than 15,000 words.

4. The language may be English or Portuguese.

5. The manuscript must be of an imaginative character or descriptive of African life or thought, and suitable for general reading.

6. Each manuscript should be accompanied by a statement signed by the author declaring that it is his own unaided work and has not previously been published.

7. Manuscripts should be addressed:

'The Margaret Wrong Prize', c/o The International Committee on Christian Literature for Africa, 2 Eaton Gate, London, S.W. I.

8. Manuscripts must reach the London office of the International Committee on Christian Literature for Africa before 31 December I952.

9. In the award of the Prize the decision of the Trustees will be final. 